\title{
Kernos
}

Revue internationale et pluridisciplinaire de religion grecque antique

$5 \mid 1992$

Varia

\section{Divine Madness and Conflict at Delphi}

\section{Bernard C. Dietrich}

URL: http://journals.openedition.org/kernos/1047

DOI: $10.4000 /$ kernos. 1047

ISSN: 2034-7871

\section{Publisher}

Centre international d'étude de la religion grecque antique

Printed version

Date of publication: 1 January 1992

ISSN: 0776-3824

\section{Electronic reference}

Bernard C. Dietrich, « Divine Madness and Conflict at Delphi », Kernos [Online], 5 | 1992, Online since 19 April 2011, connection on 01 May 2019. URL : http://journals.openedition.org/kernos/1047 ; DOI : 10.4000/kernos. 1047 


\section{DIVINE MADNESS AND CONFLICT AT DELPHI}

Orgiastikos, orgasmos, orgastes were secondary formations from orgia. Orgia originally conveyed a neutral meaning describing the cultic dromena, that is calm, unexcited ritual and sacrifice ${ }^{1}$. Notions of wild, ecstatic performances orgia acquired later when associated with a particular kind of cult. From the 6th century B.C. the word assumed the status of a technical term to describe the 'private' dromena of Demeter's Eleusinian Mysteries, and in particular the mystic rites of Bacchus which provided the route of the word's semantic development ${ }^{2}$. The mystery movement in the Greek world was an archaic phenomenon, it was then that the special rites of Dionysus began to spring into prominence reflecting the contemporary urge for spiritual union with the divine.

Mystery religions had a common factor with inspirational oracles which also belonged to the archaic age rather than to prehistoric times. Inspiration, even enthusiasmos, but not divine or human frenzy : that came later and not before the end of the 5th century B.C. ${ }^{3}$ Plato defined oracular together with poetic frenzy as forms of mania : for him mantike and manike were etymologically identical ${ }^{4}$. The Pythia, he says in the same passage from Phaedrus, raved while pronouncing Apollo's oracles from the tripod, although one would have thought that any violent activity might have been dangerous on the high perch ${ }^{5}$. In fact 5 th century vases, which show her sitting calmly on the tripod ${ }^{6}$, contradict Plato's image ${ }^{7}$. The traditional account of intoxicating fumes swirling about the Pythia from a chasm in the ground arose from a confusion of the Stoic 'pneuma' doctrine and an ageless belief in subterranean caves as places of communication with divine chthonic powers. This misleading picture of Delphic oracular practice

1 5th century B.C., inscription from Miletus, SIG, 57. 4; SoPH., Trach., 765; Ant., 1013, etc.

2 Most recent discussion in W. BurkerT, Ancient Mystery Cults, Cambridge Mass., 1987, e.g. p. 2.

3 P. Murray, Poetic Inspiration in Early Greece, in JHS, 101 (1981), p. 87.

4 Phaedrus, 244a-245a.

5 K. LATTE, The Coming of the Pythia, in HThR, 33 (1940), p. 12.

6 WILLEMSEN, in $J d I, 70$ (1955), p. 85-88.

7 He also wrongly speaks of female poetesses at Dodona. 
nevertheless gained strength through the ages, because it appealed to Christian malice which was directed against a successful pagan institution 8 .

What actually happened in the adyton at Delphi must have been far less dramatic. But the temple did function as an inspirational oracle, as did all other Apolline oracles ${ }^{9}$ : indeed Delphic procedure set the standard for them in the rest of the world. The Pythia, like Cassandra, not only owed her powers to Apollo, but she was localised at Pytho: she did not arrive there with Apollo from Anatolia or anywhere else ${ }^{10}$. Her name derived from that of the place, Pytho, whose obscure etymology hints at some dark chthonic connection ${ }^{11}$, but which was far older than Apollo's manteion there. Pytho is mentioned four times in Homer and once in Hesiod, the Pythia never; but the oracle is referred to only once, and then in a later passage ${ }^{12}$.

Obviously the Pythian oracle gained its characteristic format some time during the 'Ausklang' of archaic Greece. Its unique nature corresponded to the archaic and classical view of the god at Delphi as speaking directly through his medium, just as in myth he spoke through Cassandra ${ }^{13}$. She was in many respects the Pythia's double and owed her elevated position to the fact that she was the twin sister of the Trojan seer Helenus. In Homer she still lacked the gift of prophecy, pure chance alone allowed her first to spot her father returning with Hector's body from Achilles' tent ${ }^{14}$. Cassandra only emerged as Apollo's inspired medium in Cyclic Epic and in her hapless Sibyl-like function in Aeschylus' Agamemnon ${ }^{15}$. Both prophets were closely tied to the god's new role as creator and master of the inspirational oracle at Delphi. Divine presence, divine/human communication constitute the essential

8 W. BuRKERT, Homo necans, transl. P. Bing, Berkeley, 1983, p. 122. For a full discussion of hte primary and secondary evidence see F. FONTENROSE, The Delphic Oracle, Berkeley, 1978, p. 211; cf. B.C. DIETRICH, Oracles and Divine Inspiration, in Kernos, 3 (1990), p. 12.

9 J. Fontenrose, Delphic Oracle, p. 228; Dietrich, in Kernos, 3 (1990), p. 168.

10 As LATTE argues, in $H T h R$ (1940), p. 17.

11 On the etymology of Pytho see S. LAUFFER, in RE, XXIV (1963), c. 569.

12 Od., VIII, 79-80; cf. Il., II, 519; IX, 404-405; Od., XI, 580-581; HEs., Theog., 499.

13 Deus non Cassandra loquitur, CICERo, Div., I, 66.

$14 I l ., \mathrm{XXIV}, 699$, see schol. and Leaf ad loc. She is also mentioned in $I l .$, VI, 252; XIII, 366; Od., XI, 422.

15 On Cassandra see J. Davreux, La légende de la prophétesse Cassandre, Paris, 1942; K. SCHEFOLD, Frühgriechische Sagenbilder, München, 1964, p. 24, 54, 81, 88; Hiller von Gaertringen, in Kleine Pauly, III (1979), c. 145. 
features of this arguably holiest of all Greek sanctuaries, because the Delphic community existed solely for the tendance of the sanctuary 16 .

It is important therefore to consider the sanctuary and cult in their correct chronological context without being led astray by rumours of the oracle's high antiquity : such stories were inventions to enhance the importance of the place. Also traditions of earlier lot or other forms of consultation, which are sometimes said to have preceded the inspirational kind at Delphi, do not stand up to closer examination ${ }^{17}$. They no doubt arose from the desire to link up with prehistoric Mycenaean and Homeric oracular practices that mainly depended on mechanical means consisting of the interpretation of natural phenomena or the reading of signs from the liver of sacrificial victims and the like ${ }^{18}$.

Such predominantly practical ways of divine consultation call into question the tenacious tradition of an earth oracle at Delphi, although Aeschylus speaks of one in the Eumenides (1 sq.). Yet Ge's credentials as an oracular power are poorly attested. Only two other sites are cursorily mentioned : one at Olympia ${ }^{19}$ and another in Aegira ${ }^{20}$, while her connection with Delphi rests on the chthonic nature of the cult attached to the sanctuary 21 . The link was contrived, like that of the second owner Themis : she clearly owed her position to her name whose etymology was felt to guarantee the validity of the responses. In fact the oldest accounts agree on Apollo as first comer and tenant at Delphi22; but Homer seems barely aware of an oracle there, so that its establishment came after the foundation of the remote and open sanctuary. Delphi's archaeological prehistory is unclear: there is evidence of Mycenaean settlement and cult until LH IIIC, but not of its location in relation to the historical sanctuary. The survival of

16 Cf. BURKERT, Homo Necans, p. 118.

17 This has been demonstrated by FonTenRose, Delphic Oracle, p. 210-223. For references to discussions of this point see Kernos, 3 (1990), p. 170, n. 94.

18 Kernos, 3 (1990), p. 159-166 with refs.

19 PAus., V, 14, 10.

20 PLINY, NH, XXVIII, 41, 147, but unknown to PAUS., VII, 25, 13.

21 M.P. NILsson, Geschichte der griechischen Religion, I, München, 1967³, p. 172.

22 Hom. Hymn Apollo, 182-183; 388-390; 438-451; 514-519; Alcaeus, fr. 142 Page in HImer., Or., XXXXVIII, 10-11; Chr. Sourvinou-Inwood, Myth as History : the previous owners of the Delphic Oracle, in J. BREMmER (ed.), Interpretations of Greek Mythology, London, 1987, p. 215-241. 
Mycenaean culture at Delphi is uncertain ${ }^{23}$, therefore, in view of a possible break in occupation after IIIC ${ }^{24}$. A deposit of Mycenaean goddess figurines, together with other cultic material of LH IIIB, was found near Apollo's later temple, but the major find of almost 200 such figurines came from neighbouring Marmaria beneath the temple of Athena Pronaia ${ }^{25}$ which accordingly is more likely to have been the original cult site because of Athena's link with the Helladic past ${ }^{26}$. Altogether the indications are of a less direct link between the Delphic sanctuary and the Mycenaean remains there.

So it seems unlikely for the Mycenaean Potnia to have survived as the shadowy presence of the earth goddess Ge in Delphi ${ }^{27}$ because, apart from other considerations, the proto-Athena goddess had been sophisticated and enjoyed worship in an urbanised setting. Delphi, on the other hand, and in contrast with cult localities of Athena, lay outside the city like the majority of other Apolline sanctuaries at Thermon, for instance, or in Ptoion, Delos, Didyma, Phanai on Chios, on Mt. Kynortion near Epidaurus and elsewhere ${ }^{28}$. Physically Apollo's shrine on the mountain shows few indications of a Bronze Age past, in fact there are hardly any signs of occupation in the sanctuary area in Protogeometric and Geometric times. The first substantial finds consisted of votive offerings from below the Sacred Way : shields, figures, bronzes and the like in great numbers second only to those from Olympia. They were offered up between 750 and 730 B.C. ${ }^{29}$, and they date the activation of the sacred precinct as a cult place in the open. Delphi's foundation more or less coincided with the rise across the Gulf of Corinth to a commercial power ${ }^{30}$. The two places were linked through the figure of Apollo who encouraged Corinth's expansion. If Pausanias recorded history rather than legend, Apollo's first temple at Delphi was

23 I have to revise my former view in Origins of Greek Religion, Berlin, 1974, p. 223-224.

24 For an account of the Mycenaean history of the site with excavation reports see V. Desborough, The Last Mycenaeans and their Successors, Oxford, 1964, p. 44; 125.

25 Desborough, $L M$, p. 43.

26 B.C. DieTRICH, Tradition in Greek Religion, Berlin, 1986, p. 46; 79.

27 J.N. Coldstream, Geometric Greece, London, 1977, p. 173.

28 Exceptions in Eretria and Cretan Dreros, ColdSTREAM, Geom. Gr., p. 327-328. Of course Apollo had a temple inside the city gates at Corinth too.

29 Coldstream, Geom. Gr., p. 178; 330.

30 Coldstream, Geom. Gr., p. 178-179; 187. 
built of bay wood, long since perished ${ }^{31}$. Its date then would be about 800 B.C., that is the time of the first tripod cauldrons there ${ }^{32}$.

The choice of site, however, had been determined by an ancient tradition of mountain cult, and that fitted Apollo's nature from earliest times. In other words, Apollo had always been at home in this kind of sanctuary as an apatropaeic figure exercising functions that overlapped with Dionysus' early character. Confusion arose between the status of the two at Delphi in respect of the oracle, and the sources disagree about who came there as the first prophet. Dionysus was said to prophesy from the Delphic tripod before Apollo by one source but an unreliable on $\mathrm{e}^{33}$. Generally, however, the roles are reversed in favour of the latter, although Dionysus' ties with Delphi were far from negligible, because it was from here that his cult actually radiated outward to other centres in Greece. Rohde's suggestion that the Delphic priesthood fostered and exported Dionysian rites from Delphi as a political move ${ }^{34}$, can only be partly true at best, and there is no documentary proof of this sort of activity 35 .

The god's link with Delphi had nothing to do with mantic skill, and Rohde's thesis that Dionysus imported the inspirational element to the Apolline oracle ${ }^{36}$ depends on preconceived ideas of Delphic history and divine function. The truth is that Dionysus was no more an oracular god by nature than his partner Apollo : only one other Dionysian oracle is known in Phocis, at Amphikleia; and that significantly had the characteristics of an incubation and healing oracle ${ }^{37}$. The Hymn to Pythian Apollo, which can probably be dated to the beginning of the 6th century B.C., mentions the god's victory over Pytho, the votive tripods, but not Dionysus nor any oracle there ${ }^{38}$.

\footnotetext{
31 PAUs., X, 5, 9.

32 Rolley, in $B C H, 97$ (1973), p. 512, n. 1.

33 Scholium on Pindar, Pythia Hypothesis (in A.B. Drachmann, éd., Scholia Vetera, p. 2).

34 E. Rohde, Psyche, II, Freiburg, $1898^{2}$, p. 54-55; H. Jeanmaire, Dionysos. Histoire du culte de Bacchus, Paris, 1951, p. 187-191; NILsson, in GGR, $\mathrm{I}^{3}$, p. 614 .

35 W. BuRKert, Greek Religion, transl. J. Raffan, Oxford, 1985, p. 224.

36 Psyche, II, p. 59.

37 PAUS., X, 33, 11. Dionysus was called iatros, healer, trough his wine, ATHEN., I, 22e; 36b; PluT., Quaest. conviv., 647a; cf. NILSSON, in GGR, $\mathrm{I}^{3}$, p. 569.

Jeanmaire, Dionysos, p. 189-190.
} 
Herodotus in his 'Egyptian' book reports the tradition that the Apolline seer Melampus introduced Dionysus' cults to Greece ${ }^{39}$. The threefold nexus, however, between both gods and prophetic activity might have been invented as late as the 5th century B.C. 40 More to the point, Teiresias' aretalogia of Dionysus in the Bacchae of Euripides praises Dionysus' all embracing force including manic and mantic possession :

Moreover, this is a god of prophecy.

His worshippers, like madmen, are endowed with mantic powers.

For when the god enters the body of a man he fills him with the breath of prophecy ${ }^{41}$.

The lines are pure theologising with maniodes and mantike deliberately juxtaposed in the text in order to show that oracular power was induced by god-sent frenzied fury. Teiresias is also aware of Dionysus' rites on Parnassus which he extolls quite independently further on in the same speech:

Some day you shall even see him bounding with his torches among the crags at Delphi, leaping the pastures

that stretch between the peaks, whirling and waving

his thyrsus : great throughout Hellas ${ }^{42}$.

The reference, of course, is to the Thyiades' wild celebrations in honour of Dionysus during his winter tenure at Delphi. But there is no connection with the god's mantic possession on the one hand, or with the Delphic sanctuary site on the other, since the women's rites were confined to the mountain and the Corycian Cave in particular. As it happens, Dionysus is poorly represented in the myth of the oracle's history and totally absent from its foundation legends ${ }^{43}$.

39 II, 49.

40 RoHDE, Psyche, p. 287, cites the passage to illustrate Dionysus' temporal priority at Delphi. But for probable dates of Melampus ant he Melampodeia epic see NILsSON, in GGR, $\mathrm{I}^{3}$, p. 675 (7th/6th century B.C.); DiETRICH, in Kernos, 3 (1990), p. 172, n. 104 with refs to more recent discussions.

41 Eur., Bacchae, 298-301. This and next passage transl. by W. Arrowsmith.

42 306-309.

43 C. Kerenyi, Dionysus. Archetypal Image of Indestructible Life, transl. R. Manstetheim, London, 1976, p. 224; JEANMAIRE, Dionysus, p. 196. 
The substance of the winter rites, which brought much suffering to the Thyiades on snowy Parnassus ${ }^{44}$, revolved about the periodic reawakening of the Divine Child Dionysus in the liknon or winnowing basket. Their fame attracted participants from Athens and other Greek cities who defied the rigours of nature in an annual pilgrimage to Delphi in order to celebrate the god's death and reappearance ${ }^{45}$. Both events fell within the same festival sometime near the end of the god's stay, that is on or before the 7th day of Bysios when Apollo returned to his seat in Delphi. Originally the rites had been trieteric with an intercalary or idle year between performances. The reason for this practice is hard to fathom : Nilsson compares the practice of allowing fields to lie fallow for one year between seedings ${ }^{46}$. But Dionysus was imagined as absent for the whole year 47 , which suggests that the symbolism of renewal in the festival could not have been directly tied to the solar calendar with its seasonal cycle of vegetation ${ }^{48}$.

Two distinct yet nevertheless related signals seem to emerge from all this : one concerning divine renewal, and the other divine arrival from outside. A useful clue regarding the age of the rites is supplied by the Delphic month Dadaphorios which evidently derived its name from the Thyiades' torchlight procession on the occasion and which must have become part of the local calendar before its regulation prior to the end of the 7 th century B.C. ${ }^{49}$. Clearly Dionysus had also come relatively early to Delphi and arguably preceded its oracle.

The question then, which of the two gods first owned the oracle loses much of its significance in the light of what is known of Delphic history. Far more interesting are the reasons for the oracle's foundation and its connection with two basically non-prophetic deities who in modern opinion symbolised polar opposites in the Greek religious spectrum. 19th century romanticism created an artificial antithesis between sublime Apolline reason and the irrational, albeit immensely powerful,

44 PAUS., X, 32, 5.

45 Paus., X, 4, 3; Nilsson, Griechische Feste von Religiöser Bedeutung mit Ausschluss der attischen, Leipzig, 1906, p. 284.

$46 G G R, \mathrm{I}^{3}$, p. 573.

47 Kereny, Dionysos, p. 198; 214. He believes that the Delphic calendar was based ont the Sirius year, p. 205.

48 The Athenians duplicated the Delphic orgia on the 12th and 13th Anthesterion, annually reenacting the god's passion on home-ground, para etos, Paus., X, 4, 3; A. Mommsen, Feste der Stadt Athen, Leipzig, 1898, p. 398; 400.

49 NILSSON, in GGR, $\mathrm{I}^{3}$, p. 573. 
emotional forces of Dionysian cult : the one the hallmark of Classical Greece, the other alien and concealing remnants of a barbaric past. The contrast between old and new, darkness and light, chthonic and Olympian gods was first conjured up by Friedrich Schlegel to reinforce contemporary literary polemic ${ }^{50}$; but the idea caught the imagination of Nietsche and his friend Erwin Rohde and thereafter became orthodox dogma which it remains to this day 51 .

Conflict there was, but it existed within the myths and not between the two gods whose natures were not as dissimilar as might at first appear. Nor did such mythical conflict necessarily repeat historical events, as some suppose, reflecting actual resistance to an alien Dionysiac cult on the one hand, or a contest between an old prehistoric earth oracle at Delphi and an intrusive conquering Apollo on the other. Myth does not often prove a reliable source for history. The account of Apollo's succession at Delphi did not so much intend to record a hostile take-over as the orderly progression from chaos to an enlightened new dispensation 52 . Unsurprisingly, therefore, some versions of the story allow Apollo's occupancy to be achieved by peaceful means ${ }^{53}$.

The conflict lay in the killing of the Pytho by Apollo while still a babe in Leto's arms, according to Euripides ${ }^{54}$, and above all in the fight for the tripod, that is the most sacred symbol of renewal at Delphi. Both motifs enjoyed immense popularity, although the former derived from an eastern source ${ }^{55}$ and remained irrelevant to the oracular ritual ${ }^{56}$. The struggle for the tripod appeared on the earliest Geometric bronze cauldrons in Delphi reflecting the story's antiquity. From the 6th century B.C. the figures were frequently identified in vase painting as Apollo and Heracles : the match of god versus hero for the oracular seat seems curious but certainly far removed from any historical memory of a nebulous Dorian invasion ${ }^{57}$.

\section{LATTE, $H T h R, 33(1940)$, p. 9-10.}

51 For references see DieTRICH, in Kernos, 3 (1990), p. 159, n. 16.

52 Cf. Sourvinou-Inwood, Myth as History, p. 226-227; DieTrich, in Kernos, 3 (1990), p. 170.

53 Aesch., Eum., 1-8; Apollod., I, 4, 1; Plut., De def. orac., 421; Paus., X, 5, 6.

54 I. T., 1239-1244.

55 J. Fontenrose, Python. A Study of Delphic Myth and Its Origins, Berkeley, 1959; Burkert, Homo Necans, p. 121.

56 PLUT., De def. orac, $417 \mathrm{~g}-418 \mathrm{a}$.

57 S.B. LUCE, in AJA, 34 (1930), p. 313-333; E. KunZE, Olympische Forschungen, 2 (1950), p. 113-117; F. WILLEMSEN, in JdI, 70 (1953), p. 93-99; F. BROMMER, 
Burkert explains the quarrel as illustrating the two polarised groups that claim the sacrificial meat inside the tripod ${ }^{58}$. The contest somehow becomes an end in itself, since the idea of fighting remains central to all these scenes. This feature emerges clearly from one example on the bronze leg of an 8th century votive cauldron which had been dedicated in the Altis at Olympia. Here the familiar two quarreling anthropomorphic figures relate to the two lions also shown fighting on the lower register of the same fragment. The two fights balance each other in the manner of an Homeric simile in which the distinction between man and animal all but disappears 59 .

A lost play of Aeschylus, The Bassarids, appears to have dramatised an early myth of conflict between Dionysus and Apollo60. That, however, is a superficial view of the plot which conceals a rather more subtly complex theology. If the sources are right ${ }^{61}$, the tragedy tells how Orpheus scorned Dionysus for the worship of the Sun, that is Apollo, and consequently was torn limb from limb by the Bassaridae, the Maenads of Dionysus. The Muses of Apollo then gathered up his limbs and buried them 62 . In the best known version Thracian women hacked Orpheus to death. The diasparagmos, however, identified the prophet with his god Dionysus, so that the opposition lay within two separate aspects of Orpheus himself and not between his gods 63 : Orpheus, as Burkert aptly puts it 64 , became 'a victim of his own god'. In other words, the conflict once more resided within the myth of Dionysus in which Orpheus had become involved.

Of course, Dionysus and Apollo did not fight but complement one another at Delphi : the apodemia of one marked the epidemia of the other. Dionysus held sway for the three winter months and Apollo for the rest of the year; but winter did not symbolise night or darkness, because that season witnessed Dionysus' birth and joyful reawakening in the

Vasenlisten zur griechischen Heldensage, Marburg, $1960^{2}$, p. 30-38; SCHEFOLD, Frühgr. Sagenb., pl, 4 b.

Homo Necans, p. 121-122.

59 Olympia Archaeol. Museum B 1730; A. Mallwitz - H.V. Herrmann, Die Funde aus Olympia, Athens, 1980, p. 44, n. 16 with bibliography.

60 BuRKERT, Gr. Rel., p. 225.

61 For discussions see LINFORTH, in TAPhA, 62 (1931), p. 11 sq.; BICS, 30 (1983), p. 64 sq.

62 AEsch, fr. 83 Mette = Ps.-ERATOSTh., Catast., 24; cf. M.L. WEst, The Orphic Poems, Oxford, 1983, p. 12.

63 Cf. WEST, op. cit., p. 15.

64 Gr. Rel., p. 225. 
Corycian Cave on Parnassus under the care of the Thyiades. Apollo returned on the 7th of Bysios, or physios, that is the month of growth according to Plutarch 65 . In other words, both gods symbolised renewal. Nietzsche's division between reason and abandon, form and dissolution, inspiration and ecstasy, arose from a modern philosophical perception of Apollo and Dionysus in Greek religion : it was a 'genialer Irrtum ${ }^{166}$ without basis in the classical cult of the two gods in general, and their function at Delphi in particular.

The ancient view saw little discord between Apollo and Dionysus in shared cults in Thebes ${ }^{67}$, Sicilian Naxos ${ }^{68}$, and in the mysteries of Attic Phlya ${ }^{69}$ in which Apollo had the title Dionysodotes, Giver of Dionysus, or Saviour, according to the Platonic commentator Olympiodorus ${ }^{70}$. Both gods appeared side by side in Attic vase painting from the 6th century B.C. ${ }^{71}$. In Delphi the dithyramb usually marked the beginning of winter ${ }^{72}$, but on occasion Dionysus could also be praised with the Apolline paean ${ }^{73}$. The 4 th century temple divided the honours equally between the two : the east pediment showed Apollo with the Muses and the west Dionysus together with the Thyiades ${ }^{74}$, while a contemporary redfigure vase has both gods cordially shaking hands across the omphalos in the sanctuary ${ }^{75}$. The lyre and the flute, the characteristic instrument of Dionysus' restless music, are also brought together in the same scene.

65 Quaest. Graec., 292e; cf. KERENY, Dionysos, p. 217.

66 The phrase is cited by H. DoerRIE, Gottesvorstellung, in RE, Suppl. XII (1983), c. 108.

67 Apollo and Dionysus Ismenios, PAUS., IV, 27, 6.

68 Coins show the heads of both gods, P.R. FRANKE - M. HIRMER, Die griechische Münze als Kunstwerk, München, 1963, pl. 4.

69 PAUS., I, 31, 4.

70 6th century A.D., In Platonis Phaedonem Commentarii, p. 111.

$71 B M$ B 259 (ABV 331 n. 12); B 257 (ABV 401 n. 3); CVA : Gotha I (Deutschland 24), pl. 35 (1159).

72 PlUT., De E apud Delphos, 389a-c.

73 Kerenyi, Dionysos, p. 216-217; I.U. Powell, Collectanea Alexandrina, Oxford, 1925, p. 165; BURKERT, Gr. Rel., p. 225.

74 PAUS., $\mathrm{X}, 19,4$.

75 A calyx krater in the Hermitage Museum in Leningrad (Cat. 1807), $A R V^{2}$ $1185 \mathrm{n}$. 7. H. METZGER, Les représentations dans la céramique attique du IVe siècle, Paris, 1951, pl. 25. 3; NILSson, in GGR, $\mathrm{I}^{3}$, p. 614, pl. 38, 2. 
One interesting tradition remembers Sakadas of Argos who won the flute contest at the first Pythian Games in Delphi ${ }^{76}$.

Political propaganda was not responsible for, but cunningly exploited, a deep-seated affinity between the two gods that accounted for their identification as early as Aeschylus and Euripides. An Aeschylean fragment speaks of Apollo 'the ivy-crowned, the Bacchic god, the Seer ${ }^{77}$; another from the Licymnius of Euripides makes Lord Bacchus 'the Lover of the Laurel, Apollo the Healer'78. Macrobius devoted chapter 18 of the first Book of his Saturnalia to proving the identical nature of the two gods : he quotes the authority of Aristotle that 'Apollo and Liber Pater were one and the same God'79.

That may have been later theological speculation, but it was based on a close kinship of their natures. Both were generally imagined as coming from outside - Apollo's epiphany at Delphi was celebrated by an annual holiday; both needed to be welcomed to the company of gods. Apollo's arrival on Olympus is a central theme of the Homeric Hymn to the god, while Dionysus' introduction proved a popular subject on blackfigure vases from the mid-sixth century B.C. ${ }^{80}$. The Delphians called on Apollo to come to them from the land of the Hyperboreans, a fabulous land at the end of the world in the far north ${ }^{81}$. The sanctuary typically lay outside the settlement ${ }^{82}$. In the Homeric Hymn Apollo himself built it among the crags of Parnassus in so exposed and inhospitable a location that his Cretan priests took fright, not unlike the Christian clergy who felt obliged to remove the first cathedral at Salisbury to a friendlier place ${ }^{83}$. Apollo visited his sanctuary appearing like a flashing meteor ${ }^{84}$, he lacked a permanent home, as did Dionysus whom W.F. Otto well described as 'der kommende Gott' 85 . He too came from

$76 R E$, I A (1920), c. 1768-1769; W. KoLK, Der Pythische Apollonhymnus als aitiologische Dichtung, 1963, p. 41-47.

77 Fr. 341 Nauck.

78 Fr. 480 Nauck.

79 Inquiries into the Nature of the Divine, in MACRoBIUS, Sat., I, 18.

80 J. Boardman, Athenian Black figure Vases, London, 1974, p. 218; Hom. Hymn Apollo, 186.

81 Alcheus, fr. 142 Page (2 - 4 B) in Himer., Or., XXXXVIII, 10-11; cf. Plut., Mus., 14; PAus., X, 8, 10; STrabo, VIII, 75.

82 Cf. n. 28.

83 Hom. Hymn Apollo, 528-538.

84 Hymn, 440-445; Dietrich, Divine Epiphanies in Homer, in Numen, 30 (1983), p. 71.

85 W.F. Отто, Dionysos. Mythos und Kultus, Darmstadt, $1960^{3}$, p. 74-80. 
the extreme north, like his brother, where he lived in a cave ${ }^{86}$ on Mt. Pangaeus which also symbolised the north ${ }^{87}$.

There is a contrast here with the average Homeric Olympian who preferred to abstain from direct epiphany ${ }^{88}$, and who could be identified with specific localities as a rule. Invocation and physical arrival were characteristic traits of Apollo and Dionysus, and it would be a mistake to interpret these cultic aspects in historical terms, that is as signals that they were late-comers to Greece. On the contrary, both possessed excellent prehistoric credentials from as early as the Late Bronze Age. Dionysus' name occurs on two 13th century B.C. Linear B tablets from Pylos ${ }^{89}$, possibly already connected with wine ${ }^{90}$, although the context is uncertain ${ }^{91}$. But he may have been familiar to contemporary worshippers at the sanctuary of Ayia Irini on the island of Keos, where Minoan/Mycenaean cult endured into historical times, even if inscriptional proof of his name dates only from the mid-eighth century B.C. ${ }^{92}$. Apollo's direct contact with the Mycenaean world in the west seems certain at Amyclae in Laconia ${ }^{93}$, where the epithet Hyakinthios tied him to a local prehistoric Doric figure. The relationship recalls that between Apollo and Dionysus in Delphi 94.

Two aspects of the Spartan cult have considerable bearing on Apollo's and by inference on Dionysus' position in Phocian Delphi. The Amyclaean Hyacinthia shared with the Delphic Stepterion a common nature of atonement festival or 'Suehnefest' which focused on the theme

86 EuR, Rhesus, 972-973. On the Hyperboreans, NILsson, in GGR, $\mathrm{I}^{3}$, p. 566, with refs to modern discussions; HILler von GaerTRINGEN, in Kleine Pauly, 2 (1979), p. 1274-1275.

87 Pind., Pyth., IV, 180.

88 Numen, 30 (1983), p. 53-79.

89 PY Xa 102; 1419; also now in Chania apparently.

90 K. Kerenyi, Möglicher Sinn von diwonusojo und dadarejode, in Atti e Memorie del lo Congresso Intern. di Micenologia, II, Roma, 1968 (Incunabula Graeca, 24, 2), p. 1021 sq.

91 S. Hiller - O. PANAGL, Die Frühgriechischen Texte aus Mykenischer Zeit, Darmstadt, 1976, p. 293.

92 Keos K 4365; cf. DieTrICH, Tradition, p. 48.

93 B.C. Dietrich, The Dorian Hyacinthia : A Survival from the Bronze Age, in Kadmos, 14 (1975), p. 133-142; for arcaeological continuity of the site see V. Desborovah, The Greek Dark Ages, New York, 1972, p. 280; Coldstream, Geom. Greece, p. 331; more negatively, A.M. SNODGrass, The Dark Age of Greece, Edinburgh, 1971, p. 395.

94 On Hyakinthos, in Kadmos, 14 (1975), p. 139-141. 
of guilt through killing. In Sparta Hyacinthus accidentally died at the hands of Apollo, and his tomb was shown in the base of Apollo's image where a 'Voropfer' preceded the official Hyacinthia95. In Delphic myth the Python was the victim for whose death the god had to atone ${ }^{96}$. Dionysus' death and renewal were also localised at Delphi, and his tomb was said to be in the sanctuary, hence equally close to Apollo as that of Laconian Hyacinthus, although in the former case Apollo had not been the guilty party himself. Accounts of Dionysus' death and rebirth in Delphi differ, the best known perhaps being the version recorded by Callimachus and Euphorion, according to which the Titans tore apart the god, boiled his limbs and gave them to Apollo who hid the parts in the tripod. Rhea put the pieces together again and revived the young god ${ }^{97}$. His sacrifice released powerful forces of renewal. Orphic theology, however, retold the story adding moral elements to this symbolic presentation of blood sacrifice, because it disapproved of such cannibalistic rites 98 .

Sacrifice with its underlying significance lay at the heart of Delphic tradition. Plutarch mentions the 'unspeakable sacrifice' that the Hosioi performed in Apollo' shrine, namely Dionysus' dismemberment 99 which was intimately linked to his awakening by the Thyiades. The instruments of renewal like the tripod, that are involved in the Delphic myth, reveal their purpose quite transparently and have been discussed elsewhere ${ }^{100}$. Detienne well illustrates the tie between the boiling/ roasting of child Dionysus' limbs and ritual procedure of blood sacrifice with its life-renewing properties ${ }^{101}$. In another myth NeoptolemosPyrrhos came to sacrifice at Apollo's hearth in Delphi only to become the victim himself. His tomb, like that of Dionysus, was also shown in the sanctuary 102 .

95 PAUS., III, 19, 3.

96 Nilsson, Feste, p. 150-157; DiETRICH, Reflections on the Origins of Oracular Apollo, in BICS, 25 (1978), p. 8-9.

97 CALlim., fr. 517/643, and EupHorion, fr. 13 P.

98 For a discussion of variants and their significance, WEST, Orphic Hymns, p. $150-152$.

99 Is. et Os., 365a; De def. or., 438b; Quaest. graec., 292d; De E, 389c; BURKERT, Homo Necans, p. 124-125.

100 BICS, 25 (1978), p. 5-7.

101 M. Detienne, Dionysus Slain, transl. M \& L Muellner, Johns Hopkins U. P., 1979 , p. $69 ; 73 ; 83 ; 84$, etc.

102 Paus., X, 24, 6; I, 4, 4; schol. Pind., Nem., VII, 62 c. Burkert, Homo Necans, p. 119 , with full refs to modern discussion. 
Obviously Apollo assisted in the symbolic reenactment of death and renewal both in Amyclae and in Delphi. Porphyry actually preserved one, admittedly unique tradition, that Apollo himself and not the child Dionysus or Pytho lay 'buried' in the tripod in a reversal of roles ${ }^{103}$. Killing required atonement through purification for which Dionysiac and Apolline cults offered the ideal means. Renewal through purification was taught by the new mystery religions of the 6th century B.C. which developed such notions in highly ethical directions and incidentally increased the standing of Dionysus and Demeter in Athens with the active support of Peisistratus.

Apollo was the god of purification and healing par excellence; as alexikakos or apotropaios he 'appeared' and warded off evil from man and beast with the aid of the magic incantation of his music. The paean called the god and actually served to realise his epiphany at Delphi ${ }^{104}$. Much has already been said about this divine quality and need not be repeated ${ }^{105}$ : it was basic to the god and very old. Stones and pillars embodied Apollo's prophylactic powers who as Agyieus, for example, protected the city's roads and byways in this shape, or stood guard outside the gates as at Troy $\mathrm{VI}^{106}$, very much like the ancient herm or ancestor of the god Hermes, but also like the prehistoric figure of Dionysus who also operated in this way radiating apotropaeic energy through the same means of pillar, phallus and mask 107. At Amyclae Apollo Hyakinthios preserved the properties of the pillar in his curious semi-iconic image of bronze pillar with feet, arms and helmet which was reproduced on Spartan coins of the 3rd century B.C. 108

The stark contrast between the tragic killing of Hyakinthos and the joyful celebration of his return dominated the Amyclaean festival. The first day of mourning centred on the ritual meal of the kopis : there

103 Porph., V. Pyth., 16, after Antonios Diogenes, see Burkert, Homo Necans, p. 119, with full refs to modern discussions.

104 BuRKert, Homo Necans, p. 130.

105 DIETRICH, in Kernos, 3 (1990), p. 171, with references.

106 BICS, 25 (1978), p. 3.

107 DIETRICH, Tradition, p. 74-76. On the apotropaeic properties of the phallus see W. BURKERT, Structure and History in Greek Mythology and Ritual, Berkeley, 1979, (Sather Class. Lectures, 47), p. 39-41; on Hermes see H. HerTer, Hermes, in RhM, 119 (1976), p. 193-241.

108 Coins of Antigonos Doson, imperial coins of Commodus and Gallienus, ZIEHEN, Sparta (Kulte), in RE, III A, 2 (1929), c. 1458; IMHOFF-BLUMER \& GARDNER, Numismatic Commentary on Pausanias : Megarica, Corinthiaca, in $J H S, 6$ (1885), p. 63. 
followed two days of singing the joyful paean, a procession, dances, a contest and an offering of 'all fruits'109. Ritual banquet and panspermia typically belonged to 'Suehnefeste' like the Apolline Thargelia and Dionysus' Anthesteria. Both were pre-harvest festivals, the Anthesteria coming first in February/March of our calendar, and both expressed common apotropaeic features through a mixture of chthonic and joyful rites ${ }^{110}$. Hyacinthus' death parallels that of Dionysus in the Thyiadic rites. The two represented the figure of the dying young male god, the Divine Child, and accordingly can be seen as manifestations of the same religious concept, both in the shadow of Apollo 111 .

The miarai hemerai (Hesych.) of the Anthesteria described an All Souls festival and did not specifically refer to Dionysus' death; but in Delphi this also fell in the same month of Anthesterion ${ }^{112}$, and it is worth remembering that the Liknites, whom the Thyiades ceremoniously woke on Mt. Parnassos, was equally present on the second day of the Choes which belonged to the ill-omened part of the Anthesteria 113 . A red-figure chous of the late 5th century B.C. by the Eretria Painter and now in the Vlasto Collection, shows Dionysus' mask lying in the liknon ${ }^{114}$, reproducing an important scene from the Anthesteria ${ }^{115}$.

There was more than a passing similarity in the fate of the two figures : a scene on the Amyclaean altar shows Hyakinthos being conducted to Olympus in the manner of Dionysus whose figure in fact stood near by, according to Pausanias 116. Another notable point of contact between the two can be seen in the presence and function of their female followers : Dionysus' Maenads, or Thyiades at Delphi, mirrored the Hyakinthides and shared a common fate ${ }^{117}$. The latter were

109 NILSSOn, Feste, p. 129-140; DIETRICH, in Kadmos, 14 (1975), p. 134-135.

110 On the Thargelia and Anthesteria see NILSson, Feste, p. 105-115; 267-271. On purificatory ritual in the Anthesteria, DIETRICH, A Rite of Swinging during the Anthesteria, in Hermes, 89 (1961), p. 36-50.

111 On the Divine Child see DirTrich, Origins, p. 14-19; 88-90.

112 Mommsen, Feste der Stadt Athen, p. 39.

113 Hermes, 89 (1961), p. 50.

114 J.D. BEAZLEY, Attic Red-figure Vase-painters, Oxford, 1963, p. 725, n. 11.

115 M.P. Nilsson, The Dionysiac Mysteries of the Hellenistic and Roman Age, Lund, 1957, p. 30; GGR, $\mathrm{I}^{3}$, p. 588; pl. 38, 1. A. PICKARD-CAMBRIDGE, The Dramatic Festivals of Athens, Oxford, $1968^{2}$, p. 32, connects the episode with the Lenaea.

116 PAUS., III, 19, 3-4.

117 OTTO, Dionysos, p. 185. 
daughters of Hyakinthus in Apollodorus 118 , or, according to Phanodemos ${ }^{119}$, the offspring of Erechtheus, himself a chthonic god and Divine Child ${ }^{120}$. So the similarities between Sparta and Delphi offer some insight into the more complex background of the latter, especially in the relationship of Apollo with the two 'doubles' and his connection with the oracle. The orgiastic nocturnal rites drew Apollo into their circle $^{121}$, because the Thyiades performed their wild dances for both Dionysus and Apollo on Parnassos, the

mons Phoebo Bromioque sacer, cui numine mixto

Delphica Thebanae referunt trieterica Bacchae ${ }^{122}$.

Like the Bacchic rites those of Apollo Hyakinthos also assumed the character of mysteries no doubt raising the same expectations for the initiates as the cult of other mystic gods ${ }^{123}$.

Delphic tradition combined all elements in the respective myths of each of the two gods : conflict between dark and light forces, life and death and renewal through sacrificial killing. The Spartan Hyakinthides were slaughtered in bloody sacrifice for the salvation of their country ${ }^{124}$. At Delphi the symbolism of renewal was all but oversubscribed and directly involved the oracle with its central tripod, memory of cave, bee, honey and the like ${ }^{125}$. The signals in myth and ritual are plain to see, but they are not narrowly tied to the annual circle of the seasons. The path to renewal lay through purification, hence the attraction of mystery cult to the ascetic initiates offering the promise of direct contact with the divine.

Dionysus' quality resided in his unhomeric penchant for coming to his worshipper spiritually as well as physically : he led man out of himself to a better existence ${ }^{126}$. Apollo's nature, too, did not allow him to

\footnotetext{
118 APOLL., III, 212.

119 Phanodemos, fr. 3.

120 DieTRICH, Origins, p. 174.

121 Eur., Hel., 1469-1475.

122 LUCAN, V, 73-74.

123 Plut., Nairr, amat., 775d; St. Jerome, c. Jovin, I, 308 (Migne), speaks of nocturna sacra..., quae vocabantur Hyacinthia. Cf. S. WIDE, Lakonische Kulte, repr. Darmstadt, 1978, p. 288; 292-293; NILsSON, Feste, p. 137.

124 APOLLOD., III, 212; OTTO, Dionysos, p. 185.

125 BICS, 25 (1978), p. 3-7; Kernos, 3 (1990), p. 166-167.

126 H. Doerrie, Gottesvorstellung, p. 108.
} 
be tied to one city or site : he arrived from outside and Delphi celebrated the occasion of his epiphany with a public holiday. The god came in triumph, he spoke directly to those who had travelled to the remote shrine to ask his advice. Such freedom from the bonds of strict localisation earned both gods panhellenic status ${ }^{127}$.

Behind Apollo Musagetes the pleasant god of music and the lyre lies a darker figure who could inflict pestilence on mortals as in the opening of the Iliad. He had that feature in common with his Semitic model Reshef ${ }^{128}$ together with the positive quality of an apotropaeic god of healing and purification. These characteristics arguably belonged to his earliest nature and almost certainly resided in the title of Paean, the Healing-god. The familiar classical epithet occurs on a Linear B tablet from Knossos and describes an independent Minoan/Mycenaean deity $^{129}$, a precursor most likely of our god whose classical name has not been read in the documents.

But a striking feature of Apolline Delphi consists in the antiquity of its tradition which looked back to the Bronze Age not via the cult of an early Mother Goddess or chthonic earth oracle, but through the very figure of its famous tenant, although the monumental remains do not predate the archaic epoch. Apollo's remote Parnassian sanctuary in fact repeated basic characteristics of prehistoric mountain shrines which also served to protect against sickness in men and beasts, judging from the many explicit votive remains from such sites. Then divine epiphany seemed to have been more commonplace; but it is instructive to see that in these types of cult divine protection evidently filled a more immediate, albeit mundaner, need of the community than the presence of a prophet.

The amazing continuity of this kind of cult tradition under the wardenship of Apollo has been explored elsewhere. His native character as healing god well qualified him to become the bearer of an ancient tradition, and examples abound of Apollo the protector from evil, the purifyer receiving worship in mountain shrines. In at least one place in Greece, on Mt. Kynortion near Epidauros, the substance of Minoan cult

127 Cf. DoERrie, Gottesvorstellung, p. 106; 108.

128 See Dietrich, Tradition, p. 161.

129 Paian/Paean, KN V, 52; cf. Fp 354, M.G.F. VenTrIS - J. Chadwick, Documents in Mycenaean Greek, Cambridge, $1973^{2}$, p. 126; 312. 
of the Middle Bronze Age seems to have merged with the later classical form of Apollo Maleatas ${ }^{130}$.

In Greece of the 6th and 5th centuries protection and purification predominantly implied atonement from guilt in a society that had become aware of the dangers of contamination in every human action. Cults that once served basic requirements of every day life attained a high moral content in this age of ethical sensitivity. Orgiastic rites formed part of the transformation which readily fell into the purview of our two gods of epiphany and direct communication between human and divine spheres. If then the development that has been outlined here is correct, the complex tradition of the oracle at Delphi with its alliance of Apollo and Dionysus provides a model of how Greek religion evolved from past beliefs, how the new arose from the old, each stage altering to reflect the outlook of contemporary society.

University College of Wales

B.C. DIETRICH ABERYSTWYTH

130 See Dietrich, Origins, p. 290-307; Tradition, p. 24-28, with the relevant literature. The connection of Minoan peak cult with healing is most recently discussed by A.A.D. Peatfield, Minoan Peak Sanctuaries : History and Society, in OAth, 18 (1990), p. 122. 